\title{
Retraction
}

\section{Retracted: Immunization Coverage: Role of Sociodemographic Variables}

\author{
Advances in Preventive Medicine
}

Received 16 December 2014; Accepted 16 December 2014; Published 29 December 2014

Copyright (C) 2014 Advances in Preventive Medicine. This is an open access article distributed under the Creative Commons Attribution License, which permits unrestricted use, distribution, and reproduction in any medium, provided the original work is properly cited.

The paper titled "Immunization Coverage: Role of Sociodemographic Variables" [1], published in Advances in Preventive Medicine, has been retracted upon the authors' request due to a flaw in data acquisition.

\section{References}

[1] B. Sharma, H. Mahajan, and G. D. Velhal, "Immunization coverage: role of sociodemographic variables," Advances in Preventive Medicine, vol. 2013, Article ID 607935, 5 pages, 2013. 